\title{
SEMANGAT PEMBAHARUAN DAN PENEGAKAN HUKUM INDONESIA DALAM PERSPEKTIF SOCIOLOGICAL JURISPRUDENCE
}

\author{
Muhammad Junaidi \\ Dosen Fakultas Hukum Universitas Semarang (USM) \\ istitut.junaidi@gmail.com
}

\begin{abstract}
The spirit of renewal and law enforcement is often considered only based on a process of renewal and change the old Act to the new Act. If the renewal and law enforcement just conceived so, then the law will continue to be considered not present in the midst of society as part of the settlement of the problem. As a solution needs to be established is to integrate the spirit of renewal and law enforcement collaborated with social reality. Thus the ideal model is expected become law unifying identity as an expression of popular sovereignty and the pattern of State laws harmonization purposes.
\end{abstract}

Keyword: Excitement, Updates, and Sociological Jurisprudence

\begin{abstract}
Abstrak
Semangat pembaharuan dan penegakan hukum acapkali dianggap hanya bertumbu pada sebuah proses pembaharuan dan perubahan Undang-Undang lama ke Undang-Undang baru. Jika pembaharuan dan penegakan hukum hanya dikonsepsikan demikian, maka hukum akan terus dianggap tidak hadir di tengah-tengah masyarakat sebagai wujud penyelesaian masalah. Sebagai solusi yang perlu dibangun adalah mengintegrasikan semangat pembaharuan dan penegakan hukum yang dikolaborasikan dengan realitas sosial masyarakat. Model ideal yang demikian nantinya diharapkan menjadi identitas pemersatu hukum sebagai wujud kedaulatan rakyat dan pola harmonisasi tujuan Negara hukum.
\end{abstract}

Keyword: Semangat, Pembaharuan, dan Sociological Jurisprudence

\section{A. Pendahuluan}

Proses penegakan hukum di Indonesia selalu diwarnai sejarah yang kelam. Mulai dari sejarah adanya sebuah sismbul-simbul kekuasaan yang acapkali membuat hukum dan keadilan tidak bisa berkutik sampai pada sebuah kenyataan adanya upaya kriminalisisasi pimpinan lembaga Negara yang terjadi akhir-akhir ini.

Kondisi ini memungkinkan kita perlu kembali kepada sebuah real konstitusi bahwa Negara Indonesia adalah Negara hukum, bukan Negara kekuasaan. Negara hukum adalah suatu sistem kenegaraan yang diatur berdasarkan hukum yang berlaku yang berkeadilan yang tersusun dalam suatu konstitusi di mana semua orang dalam negara tersebut, baik yang diperintah maupun yang memerintah, harus tunduk hukum yang sama, sehingga setiap orang yang sama diperlakukan sama dan setiap orang berbeda diperlakukan berbeda dengan dasar pembedaan yang rasional, tanpa memandang perbedaan warna kulit, ras, gender, agama, daerah dan kepercayaan, dan kewenangan pemerintah dibatasi berdasarkan suatu prinsip distribusi kekuasaan, sehingga pemerintah tidak bertindak sewenang-wenang dan tidak melanggar hak-hak rakyat karenanya kepada rakyat diberikan peran sesuai kemampuan dan peranannya secara demokratis. $^{1}$

Disini jelas, larangan eigenrichting adalah aturan primer, di mana diasumsikan bahwa proses saling mempengaruhi berbagai kekuatan kemasyarakat yang berlangsung langgeng, jika kita tidak menghendaki kesemuanya ini

1 Munir Fuady, 2009, Teori Negara Hukum Modern (rechtstaat), Refika Aditama, Bandung, hlm. 3. 
bermuara dalam suatu kekacaubalauan umum, maka demi kepentingan semua pihak yang bersangkutan itu sendiri perlu menyatakan proses ini di dalam batas-batas aturan dan peraturan tertentu. Hal ini merupakan dasar ketentuan kentuan yang bukan semata-mata diarahkan pada persamaan tujuan yang dicapai oleh anggota masyarakat, tetapi pada upaya menciptakan dan menpertahankan persyaratan yang mau tidak mau harus dipenuhi terlebih dahulu yakni adanya suatu tertib hukum yang betul-betul terpelihara dengan jalan menerima suatu "rule of recognition" di samping pembentukan badan-badan pengadilan tercipta peluang untuk mengetahui aturan-aturan mana saja yang oleh penguasa diakui memiliki kekuatan mengikat, maupun menyelesaikan berbagai materi perselisihan yang berkaitan dengan, aturan-aturan ini, oleh wakil-wakil penguasa ${ }^{2}$.

Namun dalam praktiknya, disisi lain desain yang diciptakan dalam proses pembentukan hukum acapkali ditentukan kualitasnya oleh hakim sebagai aparat penegak hukum. Upaya pembentuk undang-undang kadang-kadang juga secara sadar menyerahkan perkembangan hukum kepada hakim. Dapat dikatakan bahwa terjadi "delegasi" kewenangan pembentukan aturan kepada hakim. Terhadap "pembentukan aturan hukum oleh hakim" ini juga dapat (telah) dilancarkan keberatan-keberatan. Bukankah hakim tidak cukup disiapkan untuk tugas pembentukan aturan. Berbeda dan kekuasaan pembentukan undang-undang, hakim yaris tidak memiliki dukungan aparat kepegawaian. Pada penataan bangunan (inrichting) kekuasaan kehakiman tidak dipikirkan kegiatan-kegiatan untuk hakim di luar peradilan yang lazim. Selanjutnya, suatu keberatan terhadap "pembentukan aturan oleh hakim" adalah bahwa hakim tidak dapat mengembangkan prakarsa-prakarsa sendiri untuk pembentukan aturan, melainkan akan harus menunggu sengketa konkret. Yang lebih besar adalah keberatan-keberatan yang menyangkut pengorganisasian dan pembentukan putusan, misalnya tidak adanya legitimasi demokratikai yang bersifat fundamental. Kadang-kadang

2 Emiritus Jhon Gillisen dan Emiritus Frits Gorle, 2005, Sejarah Hukum Suatu Pengantar, Refika Aditama, Jakarta, hlm. 31. hakim memperlihatkan secara jelas bahwa karena alasan-alasan itu tidak mau melakukan tindakan pembentukan hukum ${ }^{3}$.

Disini perlu dipertimbangkan secara tegas bagaimana upaya menguatkan kekuasaan pembaharuan dan penegakan hukum Indonesia dengan menginisiasinya sesuai kebutuhan masyarakat. Tentunya seideal mungkin hal ini harus dihadirkan dalam wujud kenyataan yang bersifat realistis. Hukum dalam padanan yang lebih umum dapat dianggap sebagai karakter yang terbuka, akan tetapi sejauhmana keterbukaan tersebut dapat dijalankan tentunya berangkat dari kualitas dari penegak hukum, bukan pada sebuah undang-undang.

\section{B. Pembahasan}

Menurut Fichte, negara bukan hanya memiliki tujuan yang negatif tetapi juga tujuan yang positif, yakni menciptakan dan memelihara ketertiban, ketenteraman dan keamanan. Pada tahun 1800 ia menerbitkan sebuah buku tentang negara dagang yang tertutup, di mana ia membela kebebasan negara dalam bidang ekonomi, demikian pula masalah-masalah sosial dikemukakannya. Dalam buku ini terdapat gagasan-gagasan yang selama revolusi Perancis, artinya pada masa Konvensi, dikenal sebagai ide komunis, yaitu bahwa pemerintah diharapkan menentukan keadaan ekonomi penduduknya. Dalam sistem gerak dinamika negara ini penduduk tidak mempunyai hak apa-apa. Dalam tahun 1848 Perancis ingin mewujudkan sistem ini, dimana negara tidak dianggap sebagai sejumlah individu, melainkan sebagai kesatuan yang mengatasinya. ${ }^{4}$

Konsep di atas, yang demikian inilah yang tentunya perlu dikoreksi apabila dihadirkan dalam upaya pembaharuan dan penegakan hukum. Tujuan Negara tersebut setidak-tidaknya yang tertuang dalam teks naskah pembukaan Undang-Undang Dasar Negara republik Indonesia tahun 1945. Dalam teks pembukaan tersebut

3 J.A Pointer, diterjemahkan oleh Arief Sidharta, 2008, Penemuan Hukum (judul asli Rechtvinding), Jendela Mas Pusaka-Anggota Ikapi, Bandung, hlm. 113.

4 J.J. Von SCHMID, 1979, Pemikiran Tentang Negara Dan Hukum Abad Kesembilanbelas (judul asli $\mathrm{Het}$ Denken Over Staat En Recht In De Negentiende Eeuw), Erlangga Kramat, Jakarta, hlm. 77-78. 
menempatkan Negara sebagai agen perekayasa dan sebagai pihak yang diberikan kewenangan oleh rakyat untuk menyelesaikan masalah rakyat dan dalam pelaksanaan tersebut rakyat bukan menjadi simbul yang diam, akan tetapi simbul dalam Negara yang selalu hidup.

Dalam wilayah yang demikian, sudah barangpasti perlu untuk menempatkan para aparat penegak hukum, dan pengambil keputusan dalam Negara dalam melakukan pembaharuan dan penegakan hukum harus melihat jauh ke depan. Rakyat harus menjadi faktor utama penentuan kualitas hukum yang diberlakukan. Dalam pandangan ini maka, Sosilogical Yurisprudence menjadi kata kunci untuk masuk dalam proses pembaharuan dan penegakan hukum.

Kongkritisasi semangat Sociological Jurisprudence banyak disinggung diantaranya oleh Rosecou Pound. Berkali-kali Pound menggunakan istilah "engineering" menjadi ciri khas dalam pembentukan hukum tidak jauh berbeda dari upaya menempatkan masyarakat sebagai aktor dan fokus utama dalam hukum.

Tujuan social engineering adalah untuk membangun suatu struktur masyarakat sedemikian rupa, sehingga secara maksimum dicapai kepuasan akan kebutuhan-kebutuhan, dengan seminimum mungkin benturan dan pemborosan. Untuk menggarap lebih lanjut pendapatnya itu, Pound mengembangkan suatu daftar kepentingan-kepentingan yang dilindungi oleh hukum, yang dibaginya dalam tiga golongan, yaitu kepentingan-kepentingan umum, sosial dan perorangan. Ke dalam kepentingan umum termasuk: a. kepentingan terhadap negara sebagai suatu badan yuridis; $b$. kepentingan terhadap negara sebagai penjaga dan kepentingan social. ${ }^{5}$

Sedangkan dalam hal ini kepentingan perorangan terdiri dari: a. pribadi (fisik, kebebasan kemauan, kehormatan, privacy dan kepercayaan serta pendapat, b. hubungan-hubungan domestik (orang tua, anak, suami-isteri, dan kepentingan substansial (milik, kontrak dan berusaha, keuntungan, pekerjaan, hubungan dengan orang lain. Kepentingan sosial meliputi:

5 Sadjipto Rahardjo, 1982, IImu Hukum, Alumni, Bandung, hIm. 266-267.
1) Keamanan umum;

2) Keamanan dan institusi-institusi sosial;

3) Moral umum;

4) Pengamanan sumber-sumber daya sosial

5) Kemajuan sosial dan

6) Kehidupan individu (pernyataan diri kesempatan kondisi kehidupan. ${ }^{6}$

Pola ideal yang perlu ditetapkan kemudian adalah dengan modal dasar minimnya konflik yang ada, sudah semestinya kualitas perundangundangan kita baik. Di samping itu ditambah dengan nilai lebih masyarakat kita yang setiap daerah memiliki norma yang berlaku di masyarakat yang bersifat berbeda antara satu dengan yang lain.

Masyarakat dengan model tanpa konflik atau masyarakat dengan kesepakatan nilai-nilai adalah masyarakat dengan tingkat perkembangan yang sederhana. Di Indonesia keadaannya dapat dihubungkan dengan masyarakat-masyarakat yang menjadi pendukung Hukum Adat dalam pengertiannya yang tradisional. Tingkat perkembangan yang masih sederhana itu antara lain nampak dalam bentuk pembagian kerja (division of labor) yang masih belum kompleks. Sebaliknya masyarakat dengan landasan konflik nilai-nilai adalah suatu masyarakat dengan tingkat perkembangan yang lebih maju yang telah mengalami pembagian kerja secara lebih lanjut. Keadaan ini memungkinkan terjadinya pembentukan kelompok-kelompok terbatas di dalam masyarakat yang menghidupkan kesadaran kelompok dengan nilai-nilainya sendiri. Dengan demikian maka kesepakatan nilai-nilai di dalam masyarakat tidak mudah terjadinya. Sebagai kelanjutannya, maka dalam pembentukan hukum masalah pilihan nilai-nilai tak dapat dihindarkan. Menurut Chambliss ada beberapa kemungkinan yang dapat terjadi pada pembentukan hukum yang demikian itu, yaitu:

1. Pembentukan hukum akan dilihat sebagai suatu proses adu kekuatan, di mana negara merupakan senjata di tangan lapisan yang berkuasa.

2. Sekalipun terdapat pertentangan nilainilai di dalam masyarakat, namun negara tetap dapat berdiri sebagai badan yang tidak memihak (value-neutral), di

6 Sadjipto Rahardjo, 1982, Ibid., hlm. 266-267. 
dalam mana nilai-nilai dan kepentingankepentingan yang bertentangan dapat diselesaikan tanpa mengganggu kehidupan masyarakat. ${ }^{7}$

Respon tersebut kemudian diinisiasi dalam sebuah pandangan teori Sociological Jurisprudence. Sociological Jurisprudence merupakan salah satu bentuk perwujudan kesatuan IImu Hukum dengan basis sosialnya (termasuk ilmu-ilmu sosial) yang kemudian dapat berakibat dalam sistem penegakan hukum khususnya melalui mekanisme peradilan, yaitu mekanisme hakim dalam memutus perkara. Problematiknya akan muncul terkait dengan kemerdekaan hakim dalam memutus perkara. Sistem peradilan bersifat authopoietic, ${ }^{6}$ tetapi juga harus melihat aspek-aspek lingkungan sosialnya. Di sinilah pentingnya seorang hakim untuk selalu memperhatikan aspek socilogik dan IImu Hukum yang digunakannya. Hakim seharusnya memahami aliran Sociological Jurisprudence dengan baik sehingga the living law, aspek sosial, politik, ekonomi dan budaya mendapat tempat dalam pertimbangan hakim untuk menghasilkan putusan yang tidak hanya memenuhi prinsip keadilan formal (formal Justice) tetapi juhakeadilan subtansial (subtantial justice) bahkan keadilan masyarakat (social justice) dalam penegakan hukum nasional ${ }^{8}$.

Sociological Jurisprudence sebenarnya diawali dengan legal realism melihat pentingnya realitas (fakta) kehidupan sebagai pembentuk hukum, yaitu fakta atau realitas yang merupakan hasil hubungan-hubungan yang telah terpola di dalam kehidupan masyarakat. Oleh karena itu, menurut aliran legal realism, peran hakim sangat penting karena di dalam memutus perkara ia harus mampu menemukan hukum yang (sebenarnya) ada di dalam kehidupan itu sendiri untuk dijadikan landasan keputusannya. Kajian hukum yang berbasis legal realism inilah yang kemudian mendorong lahirnya aliran hukum sociological jurispridence. Sociological jurispridence juga merupakan reaksi terhadap kajian legal positivism (jurisprudence) dengan latar belakang

\footnotetext{
7 Sadjipto Rahardjo, 1980, Hukum dan Masyarakat, Angkasa, Bandung, hlm. 50.

8 Suteki, 2013, Desain Hukum Di Ruang Sosial, Thafa Media, Yogyakarta, hlm. 21-22.
}

sebagaimana disebut di atas. Secara garis besar, berbeda mind-set yang dibangun antara jurisprudence dengan sociological jurisprudence: jurisprudence dibangun berbasis landasan teori yang logis, berbasis hubungan sebab-akibat, sedangkan sociological jurisprudence dibangun berbasis pengalaman hidup (experience). Dalam sociological jurisprudence, fakta (pengalaman hidup) menjadi landasan utama. $^{9}$

Semangat Sociological Jurisprudence dalam proses pembuatan maupun penegakan hukum tidak hanya dijalankan oleh hakim saja tentunya. Perlu adanya upaya sinergis dari semua kalangan untuk melihat persoalan ini sebagai wujud dari pembangunan nilai-nilai yang ada dalam ilmu hukum. Nilai inilah yang kemudian akan teraktualisasi alam bentuk kenyataan yaitu keadilan.

Sociological Jurisprudence mengamati bagaimana hukum dengan segala karakteristiknya diterapkan dan digunakan dalam dan dipakai oleh masyarakat. Pada saat hukum dijalankan terjadilah interaksi antara hukum dan perilaku masyarakat yang menggunakannya. Sociological Jurisprudence berbicara mengenai makna sosial hukum (the sosial meaning of law). Makna sosial diberikan kepada hukum melalui kontak-kontak dengan lingkungan sosial di mana hukum itu diterapkan. Pandangan Sociological Jurisprudence mengatakan bahwa peraturan hukum tidak dapat memaksakan agar isi peraturan dijalankan secara mutlak, melainkan dalam banyak hal dikalahkan oleh struktur sosial di mana hukum itu dijalankan. Penelitian tentang budaya hukum di Indonesia oleh Daniel S. Lev sebagimana dikutip Satjipto Rahardjo menunjukkan bagaimana pengertian hukum, prosedur hukum, di Jawa dikalahkan oleh pola harmoni, menjaga perasaan dan sebagainya. Maka dalam hal ini struktur sosial menjadi faktor penentu pula dalam hukum dan masyarakatpun sebenarnya turut membentuk hukum dengan memberi makna sosial kepadanya. Hubungan struktur sosial dengan hukum dapat kita amati pula dengan pemikiran ke belakang bagaimana hukum itu dibentuk dan dijalankan juga bergantung kepada struktur sosial masyarakatnya. ${ }^{10}$

\footnotetext{
9 Adji Samekto, 2015, Hukum Dalam Lintasan Sejarah, Indept Publishing, Lampung, hlm. 69.

10 Suteki, 2013, Op. cit., hlm. 34-35.
} 
Roscoe Pound membahas secara rinci, teliti dan luas terhadap Sociological Jurisprudence. Di Amerika, ia dikenal sebagai pemikir utama aliran ini. Pound memang berpandangan luas, tetapi lebih mengutamakan tujuan-tujuan praktis, yaitu dengan:

1. Membahas dampak sosial yang nyata dan peran lembaga dan pemberlakukan doktrin-doktrin hukum;

2. Mengajukan studi sosiologis berkenaan dengan studi hukum untuk menyiapkan perundang-undangan; karena hukum dianggap sebagai lembaga sosial yang dapat diperbaiki oleh usaha-usaha sosial bijaksana untuk menemukan cara-cara terbaik;

3. Mengembangkan efektivitas studi tentang cara membuat peraturan yang lebih menekankan pada tujuan sosial untuk dicapai oleh secara hukum, dan bukan pada sanksi;

4. Melakukan studi sejarah hukum sosiologis tentang dampak sosial yang ditimbulkan oleh doktrin hukum dan cara mengembangkannya;

5. Membela pelaksanaan hukum yang adil, dengan mendesak agar ajaran-ajaran hukum harus dianggap sebagai petunjuk pada hasil yang adil bagi masyarakat

6. Mengusahakan efektifnya pencapaian tujuan hukum. ${ }^{11}$

Pada sisi lain, yang lebih menarik lagi adalah ketika pembangunan hukum dan penegakan hukum melalui semangat Sociological Jurisprudence diukur melalui sebuah faktor yaitu cita-cita hukum. Cita hukum adalah maksud, semangat, visi, misi, dan obsesi yang melatarbelakangi lahirnya atau dibuatnya suatu aturan hukum yang seringkali berhubungan dengan tempat dan waktu di mana aturan tersebut dibuat. Contoh cita hukum:

1. Cita hukum dalam hal. diperkenalkannya bentuk usaha koperasi dalam hukum bisnis, yaitu untuk menolong pengusahapengusaha kecil agar dapat berusaha dengan baik, tertib, adil, dan terlindungi oleh hukum.

2. Cita hukum dalam sistem juri yang dikenal dalam sistim hukum Anglo Saxon,

11 Suteki, 2013, Ibid., hlm. 28-29. merupakan lambang keikutsertaan rakyat/ masyarakat dalam memutus perkara, juga untuk mempermudah proses pembuktian karena dalam sejarah hukum, dahulunya juri merupakan para tetangga pelaku kejahatan. ${ }^{12}$

Dalam membangunan konsep cita-cita, pastinya masyarakat tidak akan salah dalam menempatkan diri. Bahkan cita-cita tumbuh dan berkembang seiring dengan pertumbuhan dan perkembangan masyarakat. Berbeda dengan doktrin positivisme hukum yang terlalu dipaksakan jika menakar kualitasnya dengan melihat dalam perspektif keluhuran cita-cita. Oleh karenanya tepat sekali jika positivisme hukum harus dibebaskan dari kekakuan dirinya. ${ }^{13}$

Diakhir tulisan ini sekiranya untuk memberikan pemahaman yang kuat dalam upaya penguatan argumentasi hukum dalam tulisan penulis di atas, penulis perlu merujuk pada kondisi eropa. Di Eropa hukum tumbuh berseiring dengan pertumbuhan masyarakatnya. Kita dapat mengatakan bahwa perkembangan hukum di Eropa bersifat teratur, tahap demi tahap dilalui dengan mulus, evolutif sehingga dapat dikatakan sebagai perkembangan yang bersif at "history" bukan "a history". Di bagian awal sudah kemukakan bahwa tipe hukum sangat terkait dengan tipe masyarakatnya. Tidak mungkin digunakan tipe hukum modern saat tipe masyarakatnya adalah feodalisme atau sebaliknya. Apabila disimak perkembangan masyarakat, tampak bahwa kemunnculan tipe masyarakat sipil atau civil society, merupakan satu langkah prasyarat munculnya Negara modern konstitusional dengan penggunaan hukum modern. Dapat pula dikatakan bahwa munculnya masyarakat sipil (civil society) menjadi prasyarat untuk munculnya hukum modern. ${ }^{14}$

\section{Penutup}

\section{Kesimpulan}

Hukum bukan berada di ruang ilmu eksak. Hukum dianalogikan sebagai suatu bentuk

12 Munir Fuady, 2010, Dinamika Teori Hukum, Ghalia Indonesia, Bogor, hlm. 41.

13 Sukris sarmadi, 2013, Membebaskan Positivisme Hukum Ke Ranah Hukum Progresif (Studi Pembacaan Teks Hukum Bagi Penegak Hukum), Jurnal Dinamika Hukum, Vol. 12 No. 2 Mei 2012, hlm. 332.

14 Suteki, 2013, Op. Cit, hlm. 175. 
yang ada dan membaur di masyarakat. Sejauhmana hukum menjadi simbul-simbul ritus keadilan, maka sejauh itupula hukum menjadi bentuk lain dari sebuah kepastian yang bersifat mandiri dan terbuka bagi terealisasinya sebuah cita-cita.

Dalam hal ini yang perlu dipahami dalam proses semangat pembaharuan dan penegakan hukum Indonesia adalah sejauh mana hukum diukur ideal atau tidak ideal dari perspektif masyarakat. Sociological Jurisprudence melihat hukum sebagai sebuah institusi yang tidak final akan sebuah nilai. Dalam sociological jurisprudence: Jurisprudence dibangun berbasis landasan teori yang logis, berbasis hubungan sebab-akibat, sedangkan sociological jurisprudence dibangun berbasis pengalaman hidup (experience). Dalam sociological jurisprudence, fakta (pengalaman hidup) menjadi landasan utama.

Jika semangat dalam pembaharuan dan penegakan hukum selalu melihat dari fakta dan realitas, maka diharapkan hukum akan terus dianggap hidup di tengah masyarakat. Posisi hukum yang hidup dapat diasumsikan hukum dianggap mampu menjelma sebagai sarana pembaharuan masyarakat yang sadar akan cita-cita keadilan yang diharapkan.

\section{Saran.}

a. Sudah seidealnya sociological jurisprudence diutamakan sebagai landasan, baik dalam proses membuat, memahami maupun mengaplikasikan hukum

b. Aspek utama yang harus dijadikan rujukan dalam sociological jurisprudence adalah masyarakat, maka sudah seidealnya kedudukan masyarakat diprioritaskan sebagai semangat pembaharuan hukum

c. kekuatan utama dalam sociological jurisprudence sangat menempatkan masyarakat sebagai kekuatan yang final, sehingga masyarakat sudah seidealnya aktif dalam proses pembaharuan hukum.

\section{DAFTAR PUSTAKA}

\section{Buku-buku}

Adji Samekto, 2015, Hukum Dalam Lintasan Sejarah, Indept Publishing, Lampung.

Emiritus Jhon Gillisen dan Emiritus Frits Gorle, 2005, Sejarah Hukum Suatu Pengantar, Refika Aditama, Jakarta.

J.A Pointer, diterjemahkan oleh Arief Sidharta, 2008, Penemuan Hukum (judul asli Rechtvinding), Jendela Mas Pusaka-Anggota Ikapi, Bandung.

J.J. Von SCHMID, 1979, Pemikiran Tentang Negara Dan Hukum Abad Kesembilan belas (judul asli Het Denken Over Staat En Recht In De Negentiende Eeuw), Pembangunan dan Erlangga Kramat, Jakarta.

Munir Fuady, 2009, Teori Negara Hukum Modern (rechtstaat), Refika Aditama, Bandung.

Munir Fuady, 2010, Dinamika Teori Hukum, Ghalia Indonesia, Bogor.

Sadjipto Rahardjo, 1980, Hukum dan Masyarakat, Angkasa, Bandung.

1982, IImu Hukum, Alumni, Bandung.

Suteki, 2013, Desain Hukum Di Ruang Sosial, Thafa Media, Yogyakarta.

\section{Jurnal}

Sukris Sarmadi, 2013, Membebaskan Positivisme Hukum Ke Ranah Hukum Progresif (Studi Pembacaan Teks Hukum Bagi Penegak Hukum), Jurnal Dinamika Hukum, Vol. 12 No. 2 Mei 2012.

\section{Perundang-undangan}

Undang-Undang Dasar Negara Republik Indonesia Tahun 1945 